\title{
Polyphasic Analysis of Isolates from Kiwifruit Reveal New Genetic Lineages of Pseudomonas syringae pv. actinidifoliorum Look-Alike
}

\author{
Félix Morán ${ }^{1, *(\mathbb{D})}$, Ester Marco-Noales ${ }^{1}\left(\mathbb{D}\right.$, Elena Landeras ${ }^{2}$, Montserrat Roselló ${ }^{3}$, Adela Abelleira ${ }^{4}$, \\ Ana J. Gonzalez ${ }^{5}$ and María M. López ${ }^{1}$
}

1 Centro de Protección Vegetal y Biotecnología, Instituto Valenciano de Investigaciones Agrarias (IVIA), 46113 Valencia, Spain; marco_est@gva.es (E.M.-N.); mm52lopez@gmail.com (M.M.L.)

2 Laboratorio de Sanidad Vegetal, Principado de Asturias, 433011 Asturias, Spain; mariaelena.landerasrodriguez@asturias.org

3 Laboratorio de Diagnóstico Fitopatológico, Servicio de Seguridad y Control de la Producción Agraria, Generalitat Valenciana, 46460 Valencia, Spain; rosello_monper@gva.es

4 Estación Fitopatolóxica do Areeiro, Deputación de Pontevedra, 36153 Pontevedra, Spain; adela.abelleira@depo.es

5 Servicio Regional de Investigación y Desarrollo Agroalimentario (SERIDA), 33300 Asturias, Spain; anagf@serida.org

* Correspondence: Moran_fel@gva.es

check for updates

Citation: Morán, F.; Marco-Noales, E.; Landeras, E.; Roselló, M.; Abelleira, A.; Gonzalez, A.J.; López, M.M. Polyphasic Analysis of Isolates from Kiwifruit Reveal New Genetic Lineages of Pseudomonas syringae pv. actinidifoliorum Look-Alike. Agronomy 2021, 11, 2464. https://doi.org/ 10.3390/agronomy11122464

Academic Editor: Renaud Travadon

Received: 28 October 2021

Accepted: 2 December 2021

Published: 3 December 2021

Publisher's Note: MDPI stays neutral with regard to jurisdictional claims in published maps and institutional affiliations.

Copyright: (c) 2021 by the authors. Licensee MDPI, Basel, Switzerland. This article is an open access article distributed under the terms and conditions of the Creative Commons Attribution (CC BY) license (https:/ / creativecommons.org/licenses/by/ $4.0 /)$.

\begin{abstract}
Currently, kiwifruit cultivation arouses great economic interest in the agricultural sector in several countries of the European Union due to high consumer demand and good results achieved in terms of production potential and fruit quality. One of the main bacterial species that cause yield losses in kiwifruit plants is Pseudomonas syringae. Diseases such as bacterial canker, caused by pathovar (pv.) actinidiae; floral bud necrosis caused by pv. syringae and leaf spots caused by pv. actinidifoliorum (Pfm) are clear examples. Between 2014 and 2017, in the main kiwifruit producing areas in the north and east of Spain, several surveys were carried out in search of these pathogens. Analyses realized from symptomatic and asymptomatic plants of Actinidia deliciosa revealed the existence of new bacterial isolates close to Pfm. These new isolates werelow virulence pathogens similar to Pfm but belonging to a new group of $P$. syringae that affected the leaves of $A$. chinensis var. deliciosa. This study focused on the characterization and classification of these new isolates by a polyphasic approach in order to provide more information for understanding how the different populations of P. syringae affecting kiwifruit. They had the phenotypic characteristics of Pfm but by molecular approaches, they constituted a supported genetic lineage closely-related to Pfm independent of the five lineages described so far. This work revealed the great diversity found in P. syringae species affecting kiwifruit plants and supports the hypothesis that Pfm is a low virulence pathogen which is long established in Europe.
\end{abstract}

Keywords: pathovars; MLSA; virulence; classification; linage

\section{Introduction}

Pseudomonas syringae pv. actinidiae is one of over 60 P. syringae described pathovars and is subject to emergency measures that aim to prevent further spread of the pathogen in the European Union (EU) [1]. Bacterial canker of kiwifruit is an economically important disease caused by Pseudomonas syringae pv. actinidiae (Psa). It was reported for the first time in 1989 in Japan [2], then in China (1992) [3] and the same year in Korea and Italy [4,5]. From 2008, this bacterium was detected in several countries such as New Zealand [6], France [7], Spain [8], Portugal [9] Chile [10], Australia [10], Slovenia [11] and Greece [12] causing significant economic and environmental losses. Psa is currently considered the most threatening pathogen of Actinidia spp. crops worldwide; therefore, it is included in 
the list of A2 quarantine organisms of the European and Mediterranean Plant Protection Organization (EPPO) and it was the topic of a Decision of the European Commission (2012). Psa is a dangerous pathogen able to infect the plant in many different ways, via stomata, trichomes, flowers, lenticels, buds, leaf abscission scars and pruning cuts [13]. The characteristic symptoms of the disease caused by Psa consist of angular brown spots surrounded by a yellow halo in leaves and twigs and, if the environmental conditions are appropriate, cankers with white to reddish exudate are produced in the trunks, leaders and canes. These symptoms, that usually occur in early spring, are commonly accompanied by wilting and, in many cases, plant death, especially in cultivars of high susceptibility

There are different populations or biovars of Psa distributed around the world [14]. Until 2014, four biovars of Psa, which differ in geographic location and degree of virulence, were described: biovar 1, isolated in Japan and Italy before 2008 and characterized for its low virulence in kiwifruit plants; biovar 2, which was only reported in Korea; biovar 3, which was responsible for extensive damage in kiwifruit farming around the world and was characterized by its high virulence; and lastly, biovar 4, considered to have a low virulence since it is not capable of causing cankers; the symptomatology in leaves is minor and does not cause plant death [15]. Recently, through a comparative analysis at the phenotypic, genetic and phylogenetic levels, strains of biovar 4 were reclassified and renamed as P. syringae pv. actinidifoliorum pv. nov. (Pfm) [16]. Leaf symptoms caused by Pfm are quite similar to those caused by strains of biovar 3, and, in contrast to strains of the other biovars, Pfm strains do not induce neither shoot dieback nor canker formation. Apparently, the pathovar actinidifoliorum does not have a significant economic impact on kiwifruit production up to now [16]. Finally, two new biovars (biovar 5 and 6) were reported in Japan $[17,18]$. Biovar 5 was identified only in a limited area, showing that it may be endemic there, and biovar 6 was only isolated from A. deliciosa 'Hayward' in Nagano Prefecture (Japan). Both new biovars are related to biovar 2 [19].

The characterization and classification of the different Psa populations in biovars were based on phenotypic test and genetic analyses. The main phenotypic characteristics studied were: the fluorescence produced on King's B medium; LOPAT tests (Levan production, Oxidase, Potato rot, Arginine dihydrolase and Tobacco hypersensitivity); INA test (Ice Nucleation Activity); GATTa tests (Gelatin Liquefaction, Aesculin hydrolysis, Tyrosinase activity, Tartrate utilization); and the metabolism of carbohydrates and virulence. In terms of genetic characterization, studies were based on: MLSA (Multi Locus Sequences Analysis); type III secretion system effector genes; and the analysis of repetitive sequences in the genome.

In Spain, between 2011 and 2012, in the province of Pontevedra (located in the northwestern Spain) Psa biovar 3 was detected for the first time in plantations of $A$. chinensis var. deliciosa and chinensis [20]. Subsequent surveys, in areas close to this province, also revealed the presence of Pfm [21]. In addition to detecting the presence of Pfm and Psa biovar 3 in kiwifruit plants, new strains were isolated from symptomatic and asymptomatic plants. These new strains presented the typical morphology of P. syringae and were positive for some tests used for Psa detection described in the EPPO protocol [22], but they were not identical. Moreover, such strains showed some phenotypic and genotypic characteristics of Pfm but differed in other traits. For this reason, initially, they were named Pfm look-alike. Therefore, the aim of this study focuses on their phenotypic and genotypic characterization, which is based on the classification and reclassification schemes typical of Psa biovars.

\section{Materials and Methods}

\subsection{Surveys and Bacterial Isolations}

Surveys looking for Psa in kiwifruit orchards were performed between 2014 and 2017 in Asturias, and other areas in Spain. Suspected samples with similar symptoms to those caused by Psa and Pfm were analyzed in the laboratory following the EPPO protocol [22]. In addition, some asymptomatic plants were also analyzed. The symptomatic plant material sampled for Psa or Pfm isolation consisted of trunk and sprouts, canes and 
shoots, including those showing cankers or other lesions, leaves, buds, and flowers or fruits with necrotic spots or necrotic lesions. In the case of isolation from bleeding cankers, samples from ooze drops were taken directly.

In kiwifruit flowers, leaves and buds with Psa like symptoms, and small pieces of infected tissue were aseptically removed and dilacerated; then, they were washed in a tube with $2-5 \mathrm{~mL}$ of a sterile saline solution during $5 \mathrm{~min}$. Washing suspensions were used for the direct isolation and DNA extraction. In asymptomatic plants, composite samples were processed, randomly selecting 30 shoots/twigs of $10 \mathrm{~cm}$ in length.

Asymptomatic composite samples were shaken in $300 \mathrm{~mL}$ of phosphate buffered saline (PBS) with Tween (2\%) in Erlenmeyer flasks on a rotary shaker at $125 \mathrm{rpm}$ for $1.5 \mathrm{~h}$ at room temperature. The washing fluid was filtered with sterile gauze and centrifuged at $10,000 \mathrm{rpm}$ for $20 \mathrm{~min}$ at $5{ }^{\circ} \mathrm{C}$. The resulting pellet was suspended in $1 \mathrm{~mL}$ of PBS and used for isolation and DNA extraction. The isolation media used were Nutrient Sucrose Agar [23] and KB medium [24], modified according to Mohan and Schaad [25].

\subsection{Detection of Psa}

Genomic DNA was extracted from each sample and isolated using the DNeasy Plant Mini Kit (Qiagen, Germantown, MD, USA). DNA extracts were stored at $-20{ }^{\circ} \mathrm{C}$. DNA was amplified by conventional PCR using two sets of primers: PsaF1/PsaR2 and PsaF3/PsaR4 [26]; and duplex PCR, with the primers KN-F/KN-R and AvrDdpx-F/AvrDdpx$\mathrm{R}$ described by Gallelli et al. [27]. Additionally, to discriminate between virulent and low virulence Psa strains a real-time PCR with the primers P3F/P5R was carried out [28]. In parallel, following the methodology described in the EPPO protocol [22], Psa isolation from plant extracts was attempted. All colonies with Psa or Pfm-like appearance were tested by biochemical and physiological tests, such as fluorescence on KB medium and LOPAT tests (levan production, oxidase, potato rot, arginine dihydrolase activity, and tobacco hypersensitivity) according to Lelliot et al. [29].

\subsection{Characterization of Pfm Look-Alike}

\subsubsection{Phenotypic Characterization}

Biochemical and physiological tests, such as fluorescence on KB medium and LOPAT (levan production, oxidase, potato rot, arginine dihydrolase, and tobacco hypersensitivity) were performed according to Lelliot et al. [29]. Ice nucleation activity (INA) according to Lindow et al. [30] and GATTa tests (gelatin liquefaction, aesculin hydrolysis, tyrosinase activity, tartrate utilization) according to Latorre and Jones [31] were also used for the isolate characterization. The hypersensitive response (HR) in lemon fruit (Citrus limon) was monitored after the injection of a bacterial suspension of $10^{8}$ colony-forming units (CFU) $\mathrm{mL}^{-1}$.

\subsubsection{Pathogenicity Assays}

The pathogenicity of Pfm look-alike isolates was assayed on leaves and stems of kiwifruit plants cv. 'Hayward'. For inoculation, bacterial suspensions of $10^{6} \mathrm{CFU} \mathrm{mL}-1$ were prepared in buffer PBS at $10 \mathrm{mM}$. Five young leaves per plant were inoculated: ten punctures per leaf were made with a sterile needle, spraying $4 \mathrm{~mL}$ of the suspension. The inoculated leaves were covered with plastic for $24 \mathrm{~h}$ to maintain high humidity.

For stems, three incisions per plant, separated by $10 \mathrm{~cm}$, were made in the lower area of the plant and volumes of $25 \mu \mathrm{L}$ of the suspension were inoculated. The inoculated plants were maintained in a biosecurity greenhouse at $90 \%$ humidity and $20 \pm 3{ }^{\circ} \mathrm{C}$ with a $12 \mathrm{~h}$ photoperiod. In all cases, the reference Pfm strain, CFBP 8039, and PBS were used as positive and negative controls, respectively. The inoculated leaves and stems were checked daily for disease symptoms. Pathogenicity assays were performed in triplicate. Scoring system used for assessment of the virulence in leaves was performed by image analysis, using the interactive application (app) "Leaf Doctor" by the University of Hawaii [32,33]. This app allows to analyse photographs of symptomatic plant organs and measure the 
percentage of affected tissue based on the recognition of pixel colours of healthy plant tissues. All the photos were captured with a white background. For the leaves and stems inoculated, Koch's postulates were verified by characterizing the re-isolated bacteria from the symptomatic parts according to EPPO protocol [22].

\subsubsection{DNA Fingerprinting Using Pulsed-Field Gel Electrophoresis (PFGE)}

Isolates were cultured in YPG broth, and agarose plugs were prepared as described by Rainey et al. [34]. DNA within the plugs was digested with PmeI Fast Digest (5 $\mu \mathrm{L}, 3 \mathrm{~h}$, $37^{\circ} \mathrm{C}$ Thermo Scientific, Waltham, MA, USA), and the obtained fragments were separated by electrophoresis in 1\% agarose gels run in $0.5 \%$ TBE buffer (Tris/borate/EDTA), using a Chef-DR III System (Bio-Rad). The running conditions were $200 \mathrm{~V}\left(6 \mathrm{~V} \mathrm{~cm}^{-1}\right)$ at $14{ }^{\circ} \mathrm{C}$ for $22 \mathrm{~h}$. The included angle was $120^{\circ}$ and initial and final switch times were $3 \mathrm{~s}$ and $30 \mathrm{~s}$, respectively [35]. Salmonella enterica serovar Braenderup H9812 strain was digested with XbaI [36] and included as size standard. The resulting profiles were analyzed, and clustering was achieved by the Unweighted-Pair Group Method with Arithmetic averages (UPGMA) and Dice's coefficient of similarity, using the software Bionumerics 6.6 (Applied Maths, Biomérieux, Marcy-l'Étoile LY, France).

\subsubsection{Housekeeping Genes Amplifications and Sequencing}

Complete DNA sequencing of the ribosomic $16 \mathrm{~S}$ gene (16S rDNA) of all selected strains was performed in the phylogenetic identification "Genetic PCR solutions" service [37]. The other four housekeeping genes: glt $A$ or cts (coding for the citrate synthase enzyme), gyrB (coding for the $\beta$ subunit of the gyrase DNA), gapA (coding for the glyceraldehyde3-phosphate dehydrogenase enzyme) and $r p o B$ (coding for the $\beta$ subunit of the RNA polymerase) were selected for MLSA analysis. These housekeeping genes are commonly used for the characterization of strains such as Pfm and Psa [16,38,39]. Housekeeping genes amplification was carried out using primers designed by Sarkar and Guttman [40] and Hwang et al. [41]. In all cases, PCR amplification was prepared in $50 \mu \mathrm{L}$ reaction volume containing 10X Standard Reaction Buffer (Biotools, Madrid Spain), $0.2 \mathrm{mM}$ each dNTP (Invitrogen, Waltham, MA, USA), $3.2 \mathrm{mM} \mathrm{MgCl} 2$ (Biotools, Madrid, Spain), $0.5 \mu \mathrm{M}$ of each primer, $1 \mathrm{U}$ of Taq DNA polymerase (Biotools, Madrid, Spain) and $5 \mu \mathrm{L}$ of DNA. Reactions were performed on a Veriti 96-well thermal cycler (Applied Biosystems) in these conditions: 5 min at $95^{\circ} \mathrm{C}$, followed by 3 cycles of: $1 \mathrm{~min}$ at $95^{\circ} \mathrm{C}, 2 \mathrm{~min}$ and $15 \mathrm{~s}$ at $55^{\circ} \mathrm{C}$ and $1 \mathrm{~min}$ and $15 \mathrm{~s}$ at $72{ }^{\circ} \mathrm{C}$; followed by 30 cycles of $35 \mathrm{~s}$ at $95^{\circ} \mathrm{C}, 1 \mathrm{~min}$ and $15 \mathrm{~s}$ at $55^{\circ} \mathrm{C}$ and $1 \mathrm{~min}$ and $15 \mathrm{~s}$ at $72{ }^{\circ} \mathrm{C}$; with a final extension of $10 \mathrm{~min}$ at $72{ }^{\circ} \mathrm{C}$. The amplification products obtained by PCR were visualized on a $1 \%$ agarose gel stained with GelRed ${ }^{\mathrm{TM}}$ (Biotium Inc., Fremont, CA, USA). Nonspecific amplifications were obtained; therefore, the amplicons were purified following the manufacturer's instructions of the kit Invisorb ${ }^{\circledR}$ Spin DNA Extraction (Invitek). DNA from purified amplicons was quantified using NanoDrop 2000C spectrophotometer (Thermofisher, Waltham, MA, USA). The purified DNA of all strains was adjusted to $20 \mathrm{ng} / \mu \mathrm{L}$ to be sequenced and stored at $-20^{\circ} \mathrm{C}$.

Purified amplicons were sequenced with a minimum of two readings (one corresponding to the direct strand and the other to the reverse strand) by Sanger sequencing procedure, using an ABI PRISM 3100 Genetic Analyzer (Applied Biosystem). Finally, the quality and alignment of direct and reverse strands of each gene and strain were checked with UGENE v1.25.0 software Unipro [42].

\subsubsection{Phylogenetic Analyses: $16 \mathrm{~S}$ rRNA and MLSA}

Multiple sequence alignment and partial concatenation of the housekeeping genes were performed using the executable file Clustal W [43] included in UGENE v1.25.0 software. To select the most suitable nucleotide substitution evolution model for phylogenetic analysis, "Find Best DNA/Protein Models" included in MEGA v.7 was used [44]. Two types of phylogenetic trees were elaborated based on distances: Neighbour -Joining (NJ) and Maximum Likelihood (ML). The robustness and reliability of the resulting nodes of 
all the trees were determined using the bootstrap test with 1000 replicates, considering significant values those greater than $70 \%$ [45].

To perform phylogenetic analysis, 356 nucleotide sequences from strains of nine pathovars of $P$. syringae were used as a reference for MLSA analysis, including the three biovars of Psa and five linages described of Pfm. All of them were obtained from the GenBank database [46].

\subsubsection{Repetitive-Sequence PCR and Detection of $s y r D, c f l$, and tox-argK Genes}

Pfm look-a-like isolates were subjected to rep-PCR fingerprint analysis using BOX, ERIC and REP primer sets according to Ferrante and Scortichini $[47,48]$. The amplification products obtained were separated by electrophoresis on a $2 \%$ agarose gel. DNA bands were stained with GelRed TM (Biotium Inc., Fremont, CA, USA) and a 100 pb molecular weight marker (New England Biolabs, Ipswich, MA, USA) was used. ICMP 9617 (Psa biovar 1), K2-Psa" (Psa biovar 2), NZ 10627 (Psa biovar 3) and Pfm (CFBP 8039) strains were used as controls. Detection of the presence of the $s y r D$ gene, that is predicted to encode two proteins that function in the cyclic lipodepsinonapeptides synthesis and export respectively, was performed by the PCR protocol described by Sorensen et al. [49]. Ability to produce phytotoxins in all analysed isolates was determined by the amplification of $c f l$ gene coding for coronatine, and the tox-argK gene cluster, coding for phaseolotoxin, following the methods proposed by Bereswill et al. [50] and Templeton et al. [51], respectively. Coronatine and phaseolotoxin detection was compared with three reference strains: IVIA 2205 (P. syringae pv. tomato), ICMP 9617 (Psa) and CFBP 8039 (Pfm).

\subsubsection{Detection of Type III Secretion System Effector Genes}

For the detection by PCR of the type III secretion system effector genes, a wide array of primers was used according to Ferrante et al. [39], excluding the primer set hopAI1. Amplification was carried out in a $25 \mu \mathrm{L}$ reaction volume containing $3 \mu \mathrm{L}$ of DNA, 10X Standard Reaction Buffer (Biotools, Spain), $0.16 \mathrm{mM}$ of each dNTP (Invitrogen, USA), $3.2 \mathrm{mM}$ of $\mathrm{MgCl}_{2}$ (Biotools, Spain), $0.4 \mu \mathrm{M}$ of each primer and $0.5 \mathrm{U}$ of Taq DNA polymerase (Biotools, Spain). The reaction mixtures were initially denatured for $1 \mathrm{~min}$ at $95{ }^{\circ} \mathrm{C}$, and then followed by 30 cycles of $30 \mathrm{~s}$ at $94^{\circ} \mathrm{C}, 45 \mathrm{~s}$ at $60^{\circ} \mathrm{C}$ and $1 \mathrm{~min}$ at $72{ }^{\circ} \mathrm{C}$, with a final extension of $7 \mathrm{~min}$ at $72{ }^{\circ} \mathrm{C}$. Reactions were performed in a Veriti 96-well thermal cycler (Applied Biosystems, USA). The amplification products obtained by PCR were visualized on a $1.5 \%$ agarose gel stained with GelRed TM (Biotium Inc., Fremont, CA, USA). A 100 nt molecular weight marker (New England Biolabs, USA) was used to compare band sizes. Pfm CFBP 8039 was used as the reference strain. Presence/absence of a band of the expected size was taken as an indication of the presence or absence of the gene in the assayed strain [39].

\section{Results}

\subsection{Surveys and Bacterial Isolations and Detection of Psa}

A total of 49 symptomatic and 70 asymptomatic plants from different locations in the north and east of Spain were processed according to the EPPO protocol (2014) for Psa diagnosis. Two conventional [26,27] and one real-time PCR [28] were performed, but Psa was not detected with certainty in any case. Amplifications by both conventional PCRs were obtained only in six samples from A. chinensis var. deliciosa (cv. 'Hayward'), but their results by the real-time PCR were negative. Of these six samples, only four showed symptoms associated with Psa (samples 4515, 4519, 4520 and 4522) and two were asymptomatic (4446 and 4447). Conventional PCRs amplifications observed in all samples consisted of one band of $175 \mathrm{nt}$ according to Rees-George et al. [26] and only one band (492 nt), of the two expected, according to Gallelli et al. [27] This patterns of PCRs results was detected only in $7.14 \%$ of the samples surveyed 
Since patterns of PCRs results are indicative of the presence of Pfm [12], the existence of this pathogen in these samples was initially suspected. Eight colonies with Pfm morphology were isolated and purified from these six samples, which showed the same pattern of PCRs typical of Pfm.

\subsection{Characterization of Pfm Look-Alike}

\subsubsection{Phenotypic Characterization}

None of the named Pfm look-alike strains showed fluorescence on a King's B (KB) medium. Regarding the LOPAT tests, all of them were negative for cytochrome c oxidase activity, were not able to use arginine as a source of carbon, and were also negative in their ability to cause potato rot. However, all of them could induce a hypersensitivity reaction in tobacco plants. Differences in the ability to produce levan were found: strains 4446-1, 4446-2, 4447, and 4515 produced levan, while strains 4519, 4520-1, 4520-2 and 4522 did not. Therefore, two LOPAT profiles were observed in this Pfm look-alike group $\left(+--_{-}+\right)$ and $(----+)$. Regarding the GATTa test, results showed that all Pfm look-alike strains were able to produce enzymes that could hydrolyze gelatin and aesculin. In reference to tyrosinase, Pfm look-alike strains 4446-1 and 4446-2 did not exhibite activity, whereas conversely strains 4447, 4515, 4519, 4520-1, 4520-2 and 4522 did. Finally, none of the Pfm look-alike strains were able to use tartrate acid as a carbon source.

\subsubsection{Pathogenicity Assays}

Twenty days post inoculation, all strains caused mild symptoms on leaves of $A$. deliciosa ('Hayward'). These symptoms consisted of necrotic spots surrounded by chlorotic halos located in the inoculation area (Figure 1a). The mean percentages of necrotic areas obtained by image analysis in Pfm look-alike strains 41 days post-inoculation range from 41 to 59\%, being similar values to those obtained in Pfm strain CFBP 8039, which were approximately around $48 \%$. Higher values (96\%) were obtained in the case of the virulent Psa strain NZ 10627 (Figure 1b). None of them could induce cankers in young stems, including the virulent strains of Psa; likely because the time was too short and humidity and temperature conditions were not optimal for the appearance of cankers.
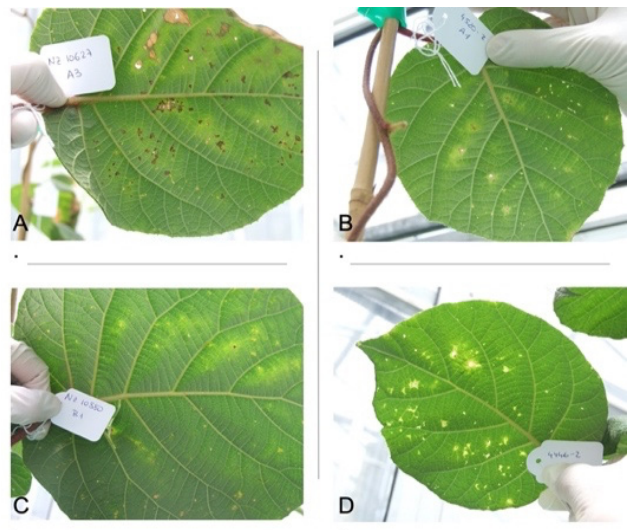

(a)

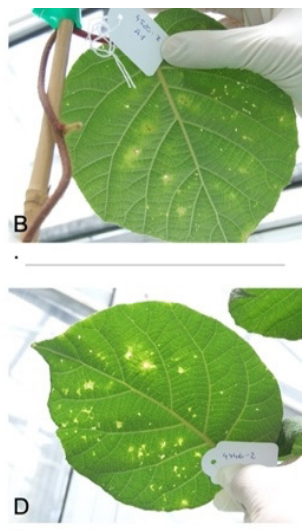

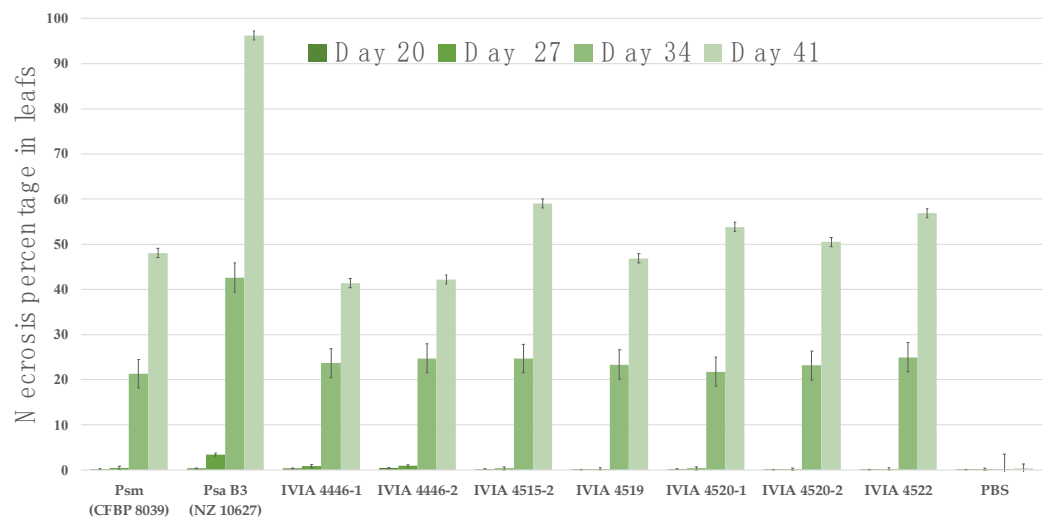

(b)

Figure 1. (a). Symptoms obtained at 34 days post-inoculation on leaves of A.chinensis var. deliciosa (cv. 'Hayward') caused by strain NZ 10627 of $P$. syringae pv actinidiae biovar 3 (A), strain CFBP 8039 of $P$. syringae pv. actinidifoliorum (C) and two isolates of Pfm look-alike IVIA 4520.2 (B) and IVIA 4446.2 (D) (b). Mean percentage values of necrosis corresponding to 20, 27, 34 and 41 days post-inoculation of seven strains characterized in this study. PBS, CFBP 8039 and NZ 10627 strains were used as controls. 
All Pfm look-alike strains and control strains of Pfm and Psa were re-isolated, tested for fluorescence on KB medium, and identified by PCR [27]. In addition, the sequencing of $r p o D$ fragment gen was performed. All the results confirmed that the re-isolates corresponded to the inoculated strains.

\subsubsection{DNA Fingerprinting Using Pulsed-Field Gel Electrophoresis (PFGE)}

Electrophoresis results after DNA digestion showed different profiles for each strain. The output tree UPGMA obtained from the gel analysis with the software Bionumerics 6.6 revealed six different clusters of Pfm look-alike: clusters from the strains 4446-1, 4447, 4515 and 4522 were close to Pfm, while clusters of IVIA 4519 and IVIA 4520-1 and 4520-2 were more distant. None of the Pfm look-alike strains grouped with Psa (Figure 2). PFGE profile from strain 4446-2 was identical to 4446-1 profile (data not shown).

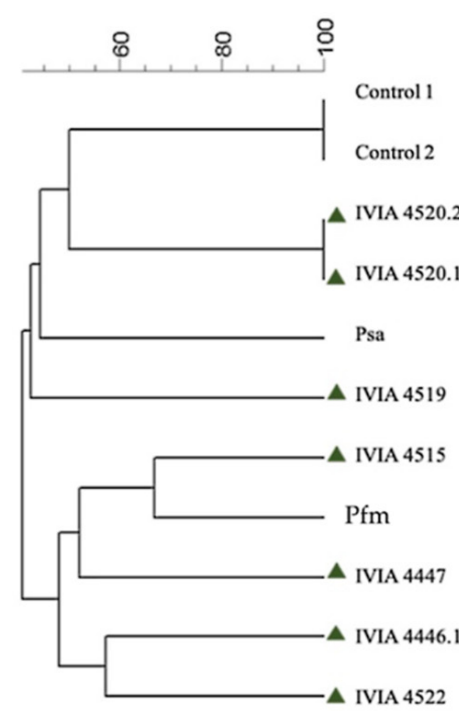

(a)

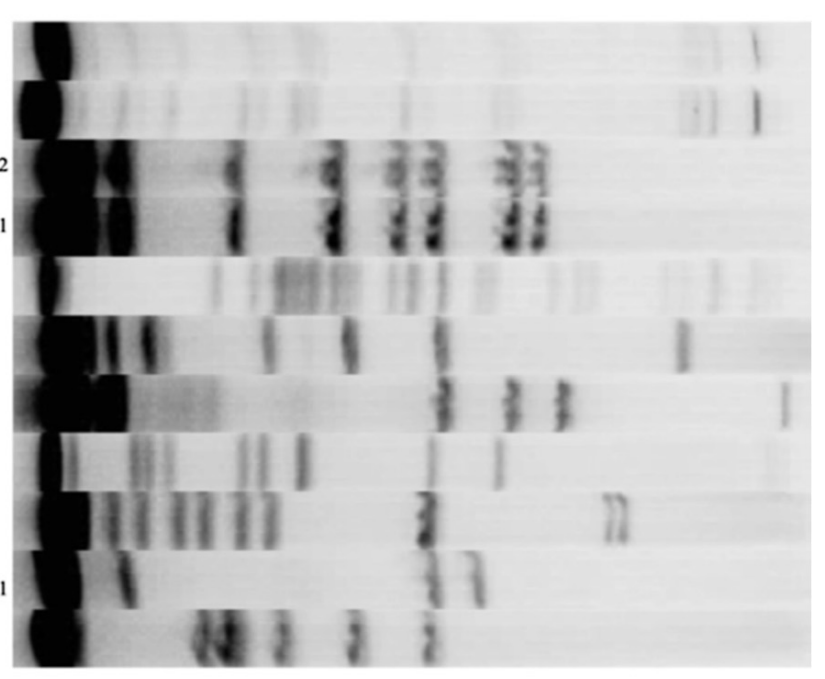

(b)

Figure 2. (a). Dendrogram based on Pulsed-Field Gel Electrophoresis profiles of 10 strains. (b). PFGE Pme-I digested DNA from strains IVIA 4446.1; 4447; 4515; 4519; 4520.1; 4520.2; 4522; CFBP 8039 (Pfm) and NZ 10627 (Psa). The DNA of the strain H9812 of Salmonella enterica serovar Braenderup used as control was digested with $\mathrm{Xba}-\mathrm{I}$ (Controls 1 and 2).

3.2.4. Phylogenetic Analyses: $16 \mathrm{~S}$ rRNA Gene and MLSA and Clonal Genealogy with gltA, gyrB, gapA and rpoD Genes

BLASTn analysis of the partial 719 nt sequence of the 16S rRNA gene from all Pfm look-alike strains (deposited in GenBank, accession numbers MW599351 to MW599358) showed a high similarity (>99\%) with P. syringae spp. isolates, including pathovars pathogenic for kiwifruit. The phylogenetic analysis of these sequences, built with the ML algorithm and using the best fitting nucleotide substitution model (Figure 3), showed that strains IVIA 4446-1 and 4446-2 were phylogenetically close to the pathovars actinidiae, pisi, phaseolicola, maculicola, theae and syringae. At the same time, strain IVIA 4520-2 formed a single distinct cluster, while the rest of the strains grouped near the fluorescens and actinidifoliorum pathovars. 


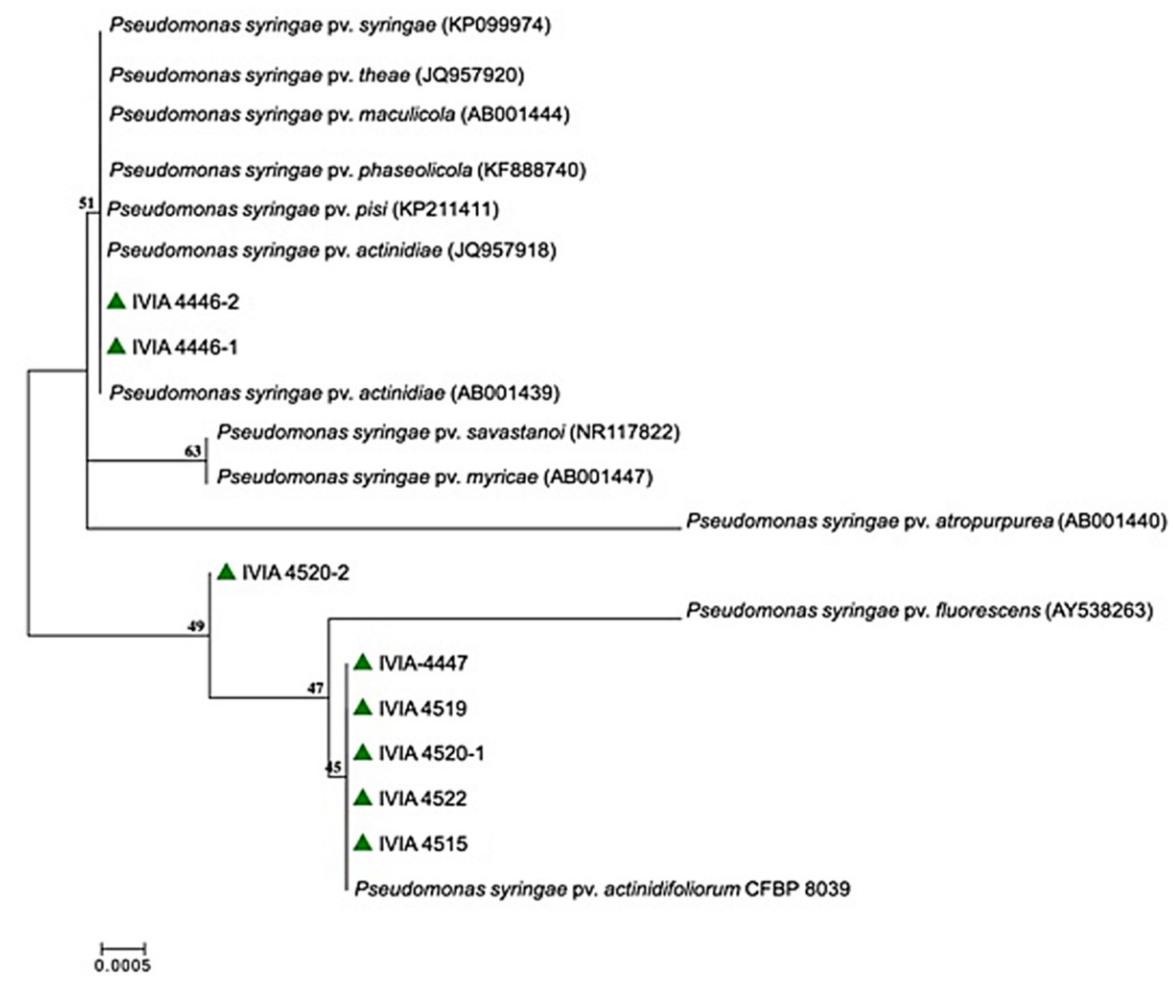

Figure 3. Phylogenetic analysis of $16 \mathrm{~S}$ rRNA partial sequences gene (719 nt) by Maximum Likelihood method based on the Hasegawa-Kishino-Yano model. Bootstraps values are shown above the branches. The analysis involved sequences of the strains characterized in this study and of 12 strains from species within the genus Pseudomonas. The number of Genbank sequences extracted from the database is indicated in brackets [52].

In the other housekeeping genes of the Pfm look-alike strains, the size of the partial sequences of gyrB, gapA, gltA and rpoD genes were $711 \mathrm{nt}, 691 \mathrm{nt}, 1143 \mathrm{nt}$ and $812 \mathrm{nt}$ (deposited in GenBank, accession number MW604723 to MW604754), respectively. The highest identity values of the partial sequences of each essential gene were $97 \%$ and $99 \%$ with P. syringae pv. actinidiae and pv. actinidifoliorum, respectively. Additionally, they showed high identity with other pathovars such as pv. tomato, pv. theae, pv. mospronorum and pv. avellanae. MLSA was carried out with $3166 \mathrm{nt}$ obtained from the partial concatenation of gltA, gyrB, gapA and rpoD genes (Figure 4). As can be seen in the ML tree, none of the Pfm look-alike strains grouped with the ten $P$. syringae selected for the analysis, not even with the pathovars of kiwifruit hosts. Pfm look-alike strains did not group with the biovars 1, 2 or 3 described for Psa, or with the Pfm cluster, that included the most recent Pfm Spanish isolates. Additionally, there was not a unique clustering of the Pfm look-alike strains. Again, five clusters of Pfm look-alike strains appeared, all with high bootstrap values ( $>85 \%)$. Pfm look-alike clusters 1, 2 and 3 were close to the actinidiae, actinidifoliorum, avellanae, mospronorum and theae pathovars, while clusters 4 and 5 were clearly separated, close to the tomato pathovar. 


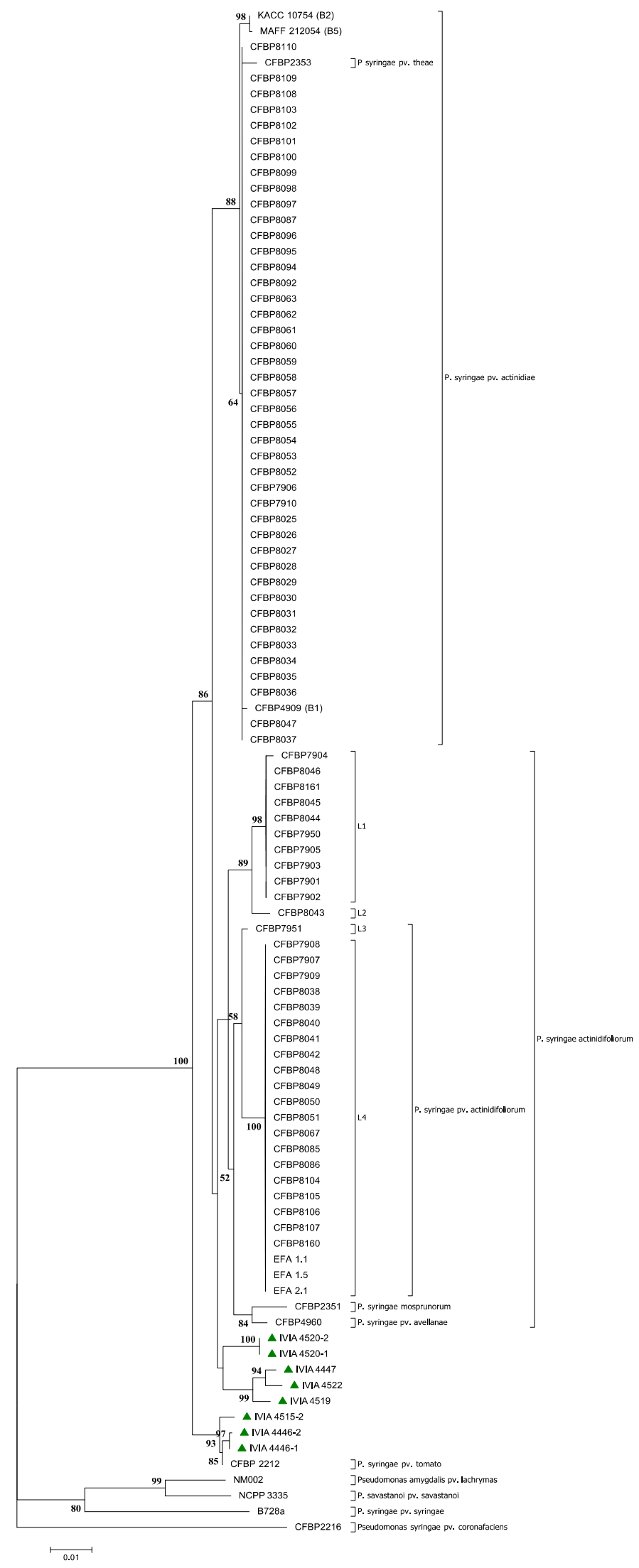

Figure 4. Phylogenetic tree based on the Maximum Likelihood method (ML) of the concatenation of $3166 \mathrm{nt}$ of the $g y r B, g a p A, r p o B$ and glt $A$ genes. The nucleotide substitution model used for tree development was the Tamura-Nei [53] with a G distribution of 0.05 . 


\subsubsection{Repetitive-Sequence PCR and Detection of $s y r D, c f l$ and tox-argK Genes}

Representative repetitive-sequence PCR (rep-PCR) fingerprint patterns for genomic DNAs corresponding to strains of the three biovars of Psa, of Pfm and Pfm look-alike were obtained with primers BOX, ERIC, and REP, according to Ferrante and Scortichini [47,48]. The corresponding dendrogram built using the UPGMA is showen in (Figure 5). Strains of the three Psa biovars displayed different patterns compared to Pfm and Pfm look-alike isolates when were analyzed by ERIC-PCR, BOX-PCR, and REP-PCR. Additionally, Pfm strains exhibited different patterns between them. Dendrograms elaborated with each repetitive-sequence PCR (data not shown), resulted in a concordant topology with the dendrogram obtained from the three rep-PCR profiles. Strains 4515 and 4446 clustered together, away from Psa and Pfm, while strains 4519, 4520, 4447 and 4522 were closer to them.

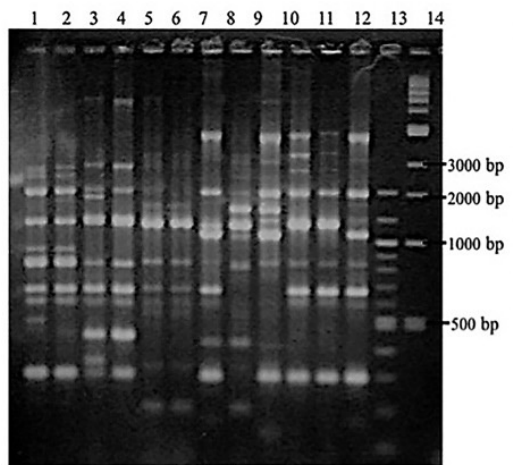

(a)

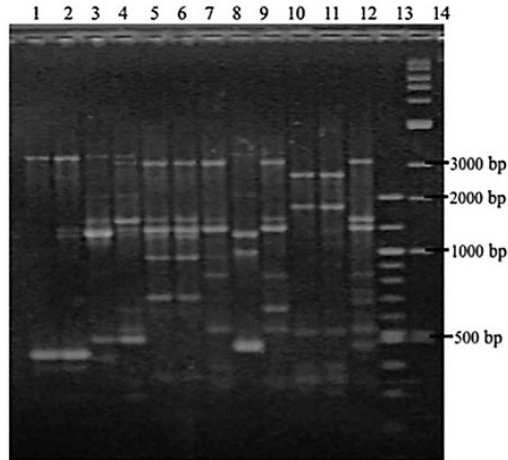

(b)

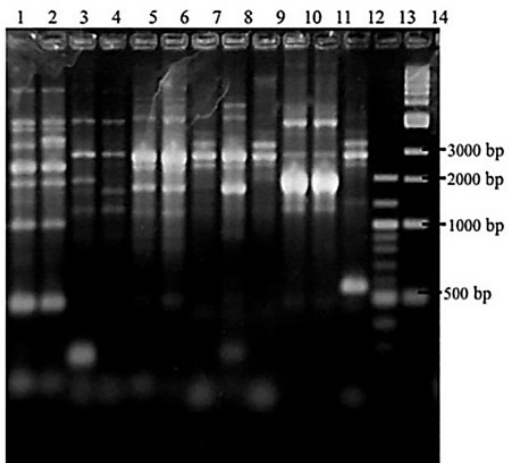

(c)

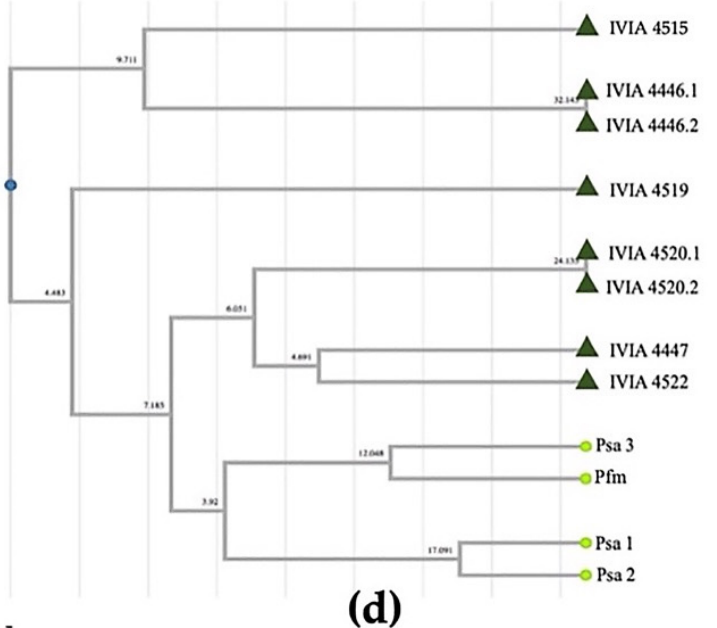

Figure 5. Electrophoresis gels of strains 9618 of Psa bv. 1 (lane 1), K2 of Psa bv. 2 (Lane 2), NZ 10627 of Psa bv. 3 (Lane 3 ), CFBP 8039 of Pfm (lane 4), and the isolates characterized in this study IVIA 4446.1, 4446.2, 4447, 4515, 4519; 4520.1, 4520.2, and 4522 (lanes 5 to 12 respectively) by (a) ERIC-PCR, (b) BOX-PCR, and (c) REP-PCR. (d) UPGMA dendrogram obtained from rep-PCR profiles.

Regarding to detection of $s y r D, c f l$ and tox-argK genes, all Pfm look-alike strains were negative for the presence of the three genes. Genes $\operatorname{syr} B$ and $\operatorname{syr} D$ encode small cyclic lipodepsinonapeptides implicated in biosynthesis and export functions, and they are typical products produced by many P. syringae pv. syringae strains. With respect to the absence of phaseolotoxin (tox-argK) and coronatine (clf) genes, it was also observed in Pfm strains. 


\subsubsection{Detection of Type III Secretion System Effector Genes}

PCR amplification of 28 types III secretion system effector genes again revealed differences between Pfm look-alike and actinidiae, actinidifoliorum and tomato pathovars. Most of these effector genes were absent in Pfm look-alike strains, in contrast to the more virulent Psa strains infecting kiwifruit plants. Compared to the Pfm pathotype (CFBP 8039), all Pfm look-alike strains showed the presence of the genes hop Y1 and hopAH2-1, and the absence of the genes hopM1 and hopAE1. One group of Pfm look-alike strains (4446-1; 4446-2; 4447; 4522 and 4519) showed the presence of the gen hopZ3; and other group (4446-1; 4446-2 and 4515) showed the presence of another effector gene (hopS1) in comparison to Pfm (Figure 6a). UPGMA dendrogram obtained from presence/absence of effector genes (Figure $6 \mathrm{~b}$ ) reveals that Pfm look-alike strains clustered separately from Psa populations, showing a closer relationship to P. syringae pv. tomato (DC3000) and pathotype Pfm strain (CFBP 8039). It can also be observed that Pfm look-alike strains do not constitute a homogeneous population in this respect, as they cluster in different groups.

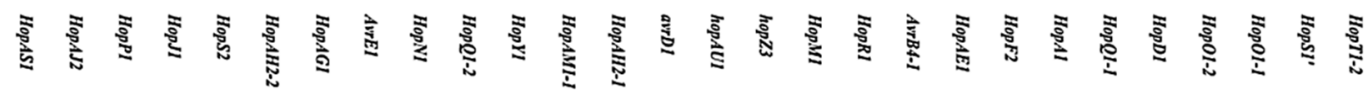

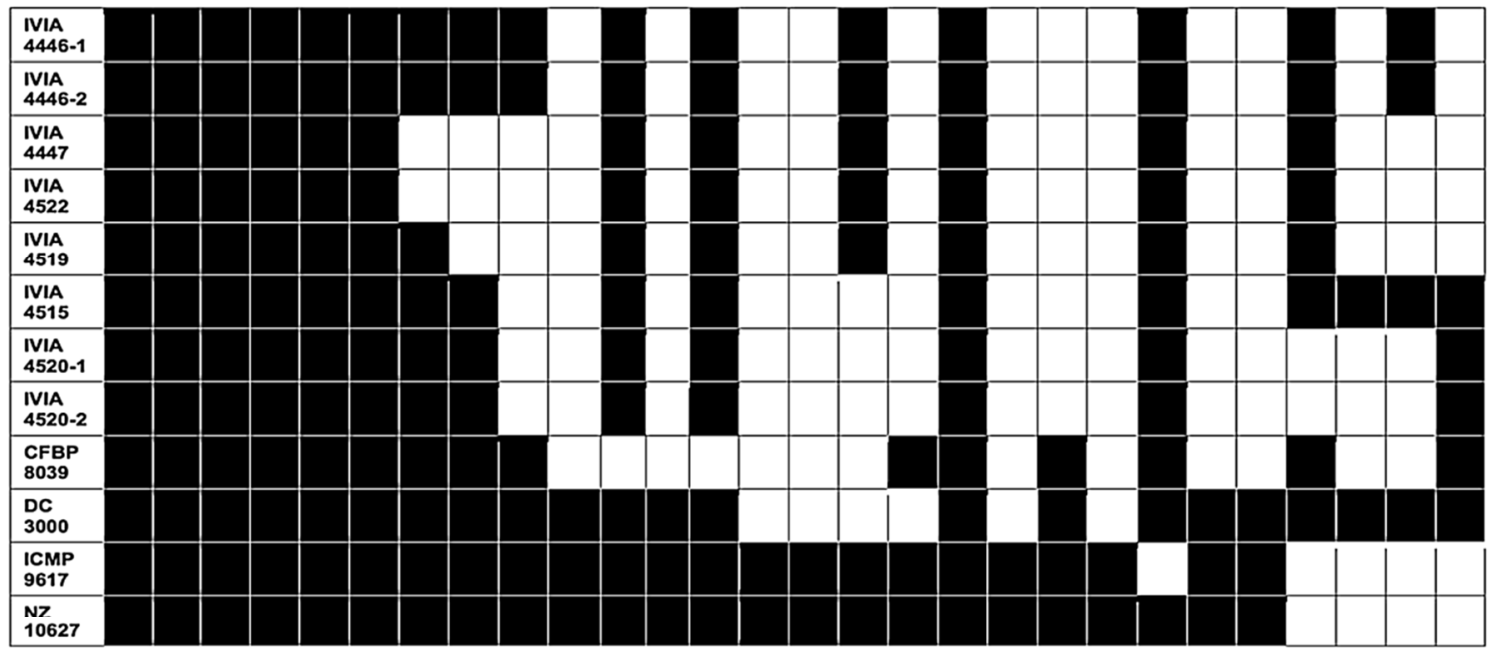

(a)

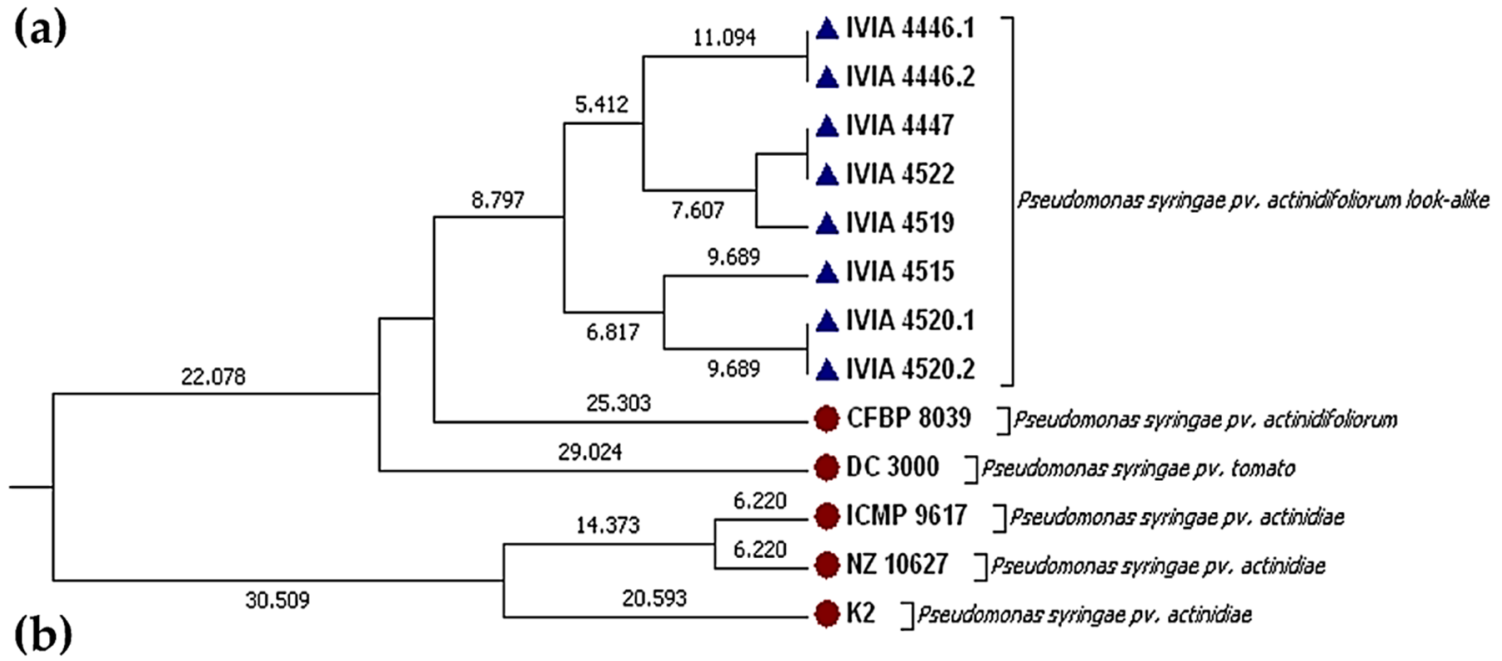

Figure 6. (a) PCR detection of presence (black squares)/absence (white squares) of type III secretion system effector genes in strains of Pseudomonas syringae pv. actinidiae (NZ10627; ICMP 9617), tomato (DC3000), actinidifoliorum (CFBP8039) and strains characterized in this study. (b) Dendrogram of strain relationships inferred by UPGMA; phylogenetic distance is shown above the branches. 


\section{Discussion}

More than 200 species were described within the genus Pseudomonas [54], whose classification methods have always been controversial. A recent study based on gene sequences and whole genome analyses of Pseudomonas spp. concludes that some strains assigned as known species should be proposed as new species and that several species were rearranged [55]. The current $P$. syringae complex encompasses over 60 pathogenic variants (pathovars) with different host ranges. It is currently divided into at least 13 phylogenetic groups (phylogroups), although this number is still debated [56]. In short, this complex bacterial group should be organized using suitable phylogenetic methods.

$P$. syringae is a diverse bacterial group consisting of strains isolated from terrestrial to aquatic environments [57]. It is considered a phylogenetic complex comprising a metapopulation distributed in different genetic ecotypes [57,58]. Traditionally, strain classification in this group was based on phenotypic characters, such as pathogenicity to one or more plant hosts. Progressively, and due to advances in molecular techniques, this intraspecific classification is now based on genotypic characters, such as whole genome sequencing, DNA-DNA hybridization, and the phylogenetic analysis of housekeeping genes, among others $[59,60]$.

As with many other bacterial pathogens, strains of $P$. syringae species were classified into pathovars. According to the Committee on the Taxonomy of Plant Pathogenic Bacteria of the International Society for Plant Pathology (ISPP), pathovar is defined as "a strain or set of strains with the same or similar characteristics, differentiated at infra subspecific level from other strains of the same species or subspecies on the basis of distinctive pathogenicity to one or more plant hosts." Therefore, the pathovar concept is not strictly related neither to the phylogeny nor to the taxonomy.

Currently, the pathovar concept is still used as a classification criterion, but increasingly this concept is accompanied by phylogenetic studies to classify new strains of $P$. syringae. A clear example is the recent reclassification of the pathovar actinidifoliorum, former biovar 4 of the pathovar actinidiae [16]. Due to these studies, which are based on a polyphasic approach and contemplate phenotypic and genetic criteria, the way in which these kiwifruit pathogenic bacteria are classified is more precisely known nowadays, and the scientific community has more information to classify new strains. Following this polyphasic classification criterium, new bacterial strains, isolated from symptomatic and asymptomatic kiwifruit plants, were characterized in this study. These new strains were present in only $7.14 \%$ of the samples analyzed, suggesting a low prevalence in kiwifruit crops. Furthermore, according to the pathogenicity assay, revealed by images analysis, these new strains are capable of infecting and producing mild symptoms on the leaves of kiwifruit plants, showing a low level of virulence. Therefore, considering the low prevalence and the low level of virulence of these new groups of $P$. syringae on kiwifruit plants, it can be assumed that they do not cause significant economic damage to kiwifruit at least in Spanish conditions. Some of these new isolates can produce levan (4446-1, 4446-2, 4447 and 4515) but others cannot; no relationship was observed between this ability and the percentage of necrosis caused in pathogenicity tests performed in kiwifruit plants. Oxidase, potato rot and arginine dihydrolase activity were negative in all cases, following a typical profile of $P$. syringae. As expected, all the strains produced tobacco-hypersensitive activity, which suggests that these bacteria strains had a pathogenic capacity. In addition, all strains studied can liquefy gelatin and also hydrolyze aesculin. Enzymes involved in these activities could contribute to virulence because they could participate in the degradation of host cell connective tissues, which aids the invasive infection process. Therefore, the results of the phenotypic analysis performed suggest that these new strains correspond to a pathogenic group similar to Pfm.

Regarding genetics analysis, these new isolates showed substantial intraspecific differences. Both repetitive-sequence PCRs, PFGE, 16S rRNA genes and MLSA analysis showed that these new strains clustered separately from the Psa populations, while showing a closer relationship to Pfm. 
Taken together the genetic and phenotypic results, these new strains could be similar to Pfm. An important result was found in the clustering obtained by MLSA, used as the gold standard for bacterial species definition [61], in which the new isolates from kiwifruit plants were clustered close to Pfm, but independently of the five linages described so far [16]. Regarding the presence of genes involved in synthesis and export of syringomycin (syr $B$ and syrD) [62], no strains contained this gene according the PCR results. Phaseolotoxin and coronatine genes (tox-argK and $c l f$ ) were also not detected. The absence of all these phytotoxin genes could also explain the mild symptoms produced by these isolates. In the same line, these new isolates showed the presence of between twelve and fifteen of the 28 effector genes of the type III secretion system analyzed, a number similar to that of Pfm strains and lower than that of Psa. The absence of many effector genes and phytotoxin genes could explain, at least in part, the low virulence of these isolates.

The kiwifruit trees from which the strains of this new lineage were isolated did not show symptoms, except for small leaf spots, and the results of the inoculation also showed smaller lesions than those caused by Psa strains. These data suggest that the damages caused by this type of strains in the field will be minimum from an economic point of view, at least in the 'Hayward' cultivar. However, assays of susceptibility on other A. chinensis var. deliciosa cultivars, as well as on other Actinidia species should be performed to decrease the level of uncertainty regarding the threat they represent for these crops. Most likely, these strains have an epiphytic stage in part of their life cycle and their colonization of the plant and symptoms expression strongly depends on the environmental conditions, and thus the latency period and disease cycle may vary in different parts of the world. In addition, many risk factors (biotic or abiotic factors that increase the probability of infestation by these pests in one area) can also play a role that is unidentified for the moment. Furthermore, inoculations on other $P$. syringae hosts could give the full picture of their potential damages and are necessary to confirm the phenotypic and genetic data that for now suggest their classification into the pathovar actinidifoliorum.

This work revealed the great diversity found in P. syringae species affecting kiwifruit plants and supports the hypothesis that Pfm is a low-virulence pathogen, long established in some areas of Europe and with several genetic lineages. In addition, the description of these new strains highlights the need to renew the classification of P. syringae strains isolated from kiwifruit. The phenotypic and genetic results presented in this work may be useful for future taxonomic classifications and the development of the more accurate detection and identification methods for the several pathovars of P. syringae; this is necessary because Psa is regulated in the EU and many countries and Pfm is not. We fully agree that additional work must be conducted to define $P$. syringae as a species and to understand the processes that affect the evolution of $P$. syringae populations [60].

Author Contributions: Conceptualization, F.M. and M.M.L.; methodology, E.L., M.R., F.M., A.A. and A.J.G.; softwares, F.M.; formal analysis, F.M.; investigation, F.M. and M.M.L.; resources, A.A., M.M.L.; data curation, F.M. and M.M.L.; writing—original draft preparation, F.M.; writing—review and editing, M.R., E.M.-N., M.M.L.; visualization, M.M.L.; supervision, M.M.L., E.M.-N.; project administration, M.M.L. and F.M.; funding acquisition, M.M.L., M.R., A.A., E.L. All authors have read and agreed to the published version of the manuscript.

Funding: This research was funded by the INIA Project "El chancro bacteriano del kiwi, causado por la bacteria emergente Pseudomonas syringae pv. actinidiae: situación en la Comunidad Valenciana, métodos de diagnóstico y caracterización de cepas", grant number RTA2013-00072-C03-03. In addition, F.M. is the recipient of a fellowship co-funded by IVIA and European Social Fund.

Acknowledgments: We thank to Javier Peñalver, Clara Morente, Adela Monterde and Silvia Barbé for technical support.

Conflicts of Interest: The authors declare no conflict of interest. The funders had no role in the design of the study; in the collection, analyses, or interpretation of data; in the writing of the manuscript, or in the decision to publish the results. 


\section{References}

1. Vogelaar, M.; Schenk, M.; Delbianco, A.; Graziosi, I.; Vos, S. Pest survey card on Pseudomonas syringae pv. actinidiae. EFSA 2020, 17, 1986E. [CrossRef]

2. Takikawa, Y.; Serizawa, S.; Ichikawa, T.; Tsuyumu, S.; Goto, M. Pseudomonas syringae pv. actinidiae pv. nov.: The causal bacterium of banker of biwifruit in Japan. Jpn. J. Phytopathol. 1989, 55, 437-444.

3. Wang, Z.T. Identification of the pathogenic bacterium for bacterial canker on actinidia in sichuan. J. Southwest Agric. Univ. 1992, 46,6 .

4. Koh, Y.; Chung, H.; Cha, B.; Lee, D. Outbreak and spread of bacterial canker in kiwifruit. Korean. Korean J. Plant Pathol. 1994, 10, 69-72.

5. Scortichini, M. Occurrence of Pseudomonas syringae pv. actinidiae on kiwifruit in Italy. Plant Pathol. 1994, 43, 1035-1038. [CrossRef]

6. $\quad$ Everett, K.R.; Taylor, R.K.; Romberg, M.K.; Rees-George, J.; Fullerton, R.A.; Vanneste, J.L.; Manning, M.A. First report of Pseudomonas syringae pv. actinidiae causing kiwifruit bacterial canker in New Zealand. Australas. Plant Dis. Notes 2011, 6, 67-71. [CrossRef]

7. Vanneste, J.L.; Poliakoff, F.; Audusseau, C.; Cornish, D.A.; Paillard, S.; Rivoal, C.; Yu, J. First report of Pseudomonas syringae pv. Actinidiae, the causal agent of bacterial canker of kiwifruit in France. Plant Dis. 2011, 95, 1311. [CrossRef]

8. Abelleira, A.; López, M.M.; Peñalver, J.; Aguín, O.; Mansilla, J.P.; Picoaga, A.; García, M.J. First report of bacterial canker of kiwifruit caused by Pseudomonas syringae pv. actinidiae in Spain. Plant Dis. 2011, 95, 1583. [CrossRef]

9. Balestra, G.M.; Renzi, M.; Mazzaglia, A. First report of bacterial canker of Actinidia deliciosa caused by Pseudomonas syringae pv. actinidiae in Portugal. New Dis. Rep. 2010, 22, 10. [CrossRef]

10. EPPO Global Database. Pseudomonas syringae pv. actinidiae (PSDMAK), Distribution. Available online: https://gd.eppo.int/ taxon/PSDMAK/distribution (accessed on 5 November 2021).

11. Dreo, T.; Pirc, M.; Ravnikar, M.; Žežlina, I.; Poliakoff, F.; Rivoal, C.; Nice, F.; Cunty, A.; Ouest, A. First report of Pseudomonas syringae pv. actinidiae, the causal agent of bacterial canker of kiwifruit in Slovenia. Plant Dis. 2014, 98, 1578. [PubMed]

12. Holeva, M.C.; Glynos, P.E.; Karafla, C.D. First report of bacterial canker of kiwifruit caused by Pseudomonas syringae pv. Actinidiae in Greece. Plant Dis. 2015, 99, 723. [CrossRef]

13. Donati, I.; Cellini, A.; Sangiorgio, D.; Vanneste, J.L.; Scortichini, M.; Balestra, G.M.; Spinelli, F. Pseudomonas syringae pv. actinidiae: Ecology, infection dynamics and disease epidemiology. Microb. Ecol. 2020, 80, 81-102. [CrossRef] [PubMed]

14. Morán, F.; Marco-Noales, E.; Escrich, A.; Barbé, S.; López, M.M. Biodiversity and biogeography of three Pseudomonas syringae pathovars which affect kiwi fruit cultivation. Biodivers. Online J. 2018, 1, 1-3.

15. Vanneste, J.L.; Yu, J.; Cornish, D.A.; Tanner, D.J.; Windner, R.; Chapman, J.R.; Taylor, R.K.; Mackay, J.F.; Dowlut, S. Identification, virulence, and distribution of two biovars of Pseudomonas syringae pv. actinidiae in New Zealand. Plant Dis. 2013, 97, 708-719. [CrossRef] [PubMed]

16. Cunty, A.; Poliakoff, F.; Rivoal, C.; Cesbron, S.; Fischer-Le Saux, M.; Lemaire, C.; Jacques, M.A.; Manceau, C.; Vanneste, J.L. Characterization of Pseudomonas syringae pv. actinidiae (Psa) isolated from France and assignment of Psa biovar 4 to a de novo pathovar: Pseudomonas syringae pv. actinidifoliorum pv. nov. Plant Pathol. 2015, 64, 582-596. [CrossRef]

17. Sawada, H.; Miyoshi, T.; Ide, Y. Novel MLSA group (Psa5) of Pseudomonas syringae pv. actinidiae causing bacterial canker of kiwifruit (Actinidia chinensis) in Japan. Jpn. J. Phytopathol. 2014, 80, 171-184. [CrossRef]

18. Sawada, H.; Kondo, K.; Nakaune, R. Novel biovar (biovar 6) of Pseudomonas syringae pv. actinidiae causing bacterial canker of kiwifruit (Actinidia deliciosa) in Japan. Jpn. J. Phytopathol. 2016, 82, 101-115. [CrossRef]

19. Fujikawa, T.; Sawada, H. Genome analysis of Pseudomonas syringae pv. actinidiae biovar 6, which produces the phytotoxins, phaseolotoxin and coronatine. Sci. Rep. 2019, 9, 3836. [CrossRef] [PubMed]

20. Abelleira, A.; Ares, A.; Aguín, O.; Picoaga, A.; López, M.M.; Mansilla, P. Current situation and characterization of Pseudomonas syringae pv. actinidiae on kiwifruit in Galicia (northwest Spain). Plant Pathol. 2014, 63, 691-699. [CrossRef]

21. Abelleira, A.; Ares, A.; Aguin, O.; Peñalver, J.; Morente, M.C.; López, M.M.; Sainz, M.J.; Mansilla, J.P. Detection and characterization of Pseudomonas syringae pv. actinidifoliorum in kiwifruit in Spain. J. Appl. Microbiol. 2015, 119, 1659-1671. [CrossRef] [PubMed]

22. EPPO. PM 7/120 (1) Pseudomonas syringae pv. actinidiae. EPPO Bull. 2014, 44, 360-375. [CrossRef]

23. Crosse, J.E. Bacterial canker of stone-fruits: Iv. investigation of a method for measuring the inoculum potential of cherry trees. Ann. Appl. Biol. 1959, 47, 306-317. [CrossRef]

24. King, E.O.; Ward, M.K.; Raney, D.E. Two simple media for the demonstration of pyocyanin and fluorescin. J. Lab. Clin. Med. 1954, 44, 301-307.

25. Mohan, S.K. An Improved Agar Plating Assay for Detecting Pseudomonas syringae pv. syringae and P. s. pv. phaseolicola in contaminated bean seed. Phytopathology 1987, 77, 1390. [CrossRef]

26. Rees-George, J.; Vanneste, J.L.; Cornish, D.A.; Pushparajah, I.P.S.; Yu, J.; Templeton, M.D.; Everett, K.R. Detection of Pseudomonas syringae pv. actinidiae using polymerase chain reaction (PCR) primers based on the 16S-23S rDNA intertranscribed spacer region and comparison with PCR primers based on other gene regions. Plant Pathol. 2010, 59, 453-464. [CrossRef]

27. Gallelli, A.; L'Aurora, A.; Loreti, S. Gene sequence analysis for the molecular detection of Pseudomonas syringae pv. actinidiae: Developing diagnostic protocols. J. Plant Pathol. 2011, 93, 425-435. 
28. Gallelli, A.; Talocci, S.; Pilotti, M.; Loreti, S. Real-time and qualitative PCR for detecting Pseudomonas syringae pv. actinidiae isolates causing recent outbreaks of kiwifruit bacterial canker. Plant Pathol. 2014, 63, 264-276. [CrossRef]

29. Lelliott, R.; Stead, D. Methods for the Diagnosis of Bacterial Diseases of Plants; Blackwell Scientific Publications: Oxford, UK, 1987; p. 216.

30. Lindow, S.E. The role of bacterial ice nucleation in frost injury to plants. Ann. Rev. Phytopathol. 1983, 21, 363-384. [CrossRef]

31. Latorre, B.A. Pseudomonas morsprunorum, the cause of bacterial canker of sour cherry in Michigan, and its epiphytic association with P. syringae. Phytopathology 1979, 69, 335. [CrossRef]

32. Pethybridge, S.J.; Nelson, S.C. Leaf Doctor: A new portable application for quantifying plant disease severity. Plant Dis. 2015, 99, 1310-1316. [CrossRef] [PubMed]

33. Leaf Doctor on the App Store. Available online: https://apps.apple.com/us/app/leaf-doctor/id874509900 (accessed on 5 November 2021).

34. Rainey, P.B.; Bailey, M.J.; Thompson, I.P. Phenotypic and genotypic diversity of fluorescent pseudomonads isolated from field-grown sugar beet. Microbiology 1994, 140, 2315-2331. [CrossRef] [PubMed]

35. Guven, K.; Jones, J.B.; Momol, M.T.; Dickstein, E.R. Phenotypic and genetic diversity among Pseudomonas syringae pv. phaseolicola. J. Phytopathol. 2004, 152, 658-666. [CrossRef]

36. Hunter, S.B.; Vauterin, P.; Lambert-Fair, M.A.; Van Duyne, M.S.; Kubota, K.; Graves, L.; Wrigley, D.; Barrett, T.; Ribot, E. Establishment of a universal size standard strain for use with the pulsenet standardized pulsed-field gel electrophoresis protocols: Converting the national databases to the new size standard. J. Clin. Microbiol. 2005, 43, 1045-1050. [CrossRef]

37. Genetic Analysis Strategies. Available online: https://geneticpcr.com/en/ (accessed on 5 November 2021).

38. Chapman, J.R.; Taylor, R.K.; Weir, B.S.; Romberg, M.K.; Vanneste, J.L.; Luck, J.; Alexander, B.J.R. Phylogenetic relationships among global populations of Pseudomonas syringae pv. actinidiae. Phytopathology 2012, 102, 1034-1044. [CrossRef]

39. Ferrante, P.; Scortichini, M. Redefining the global populations of Pseudomonas syringae pv. actinidiae based on pathogenic, molecular and phenotypic characteristics. Plant Pathol. 2015, 64, 51-62. [CrossRef]

40. Sarkar, S.F.; Guttman, D.S. Evolution of the core genome of Pseudomonas syringae, a highly clonal, endemic plant pathogen. Appl. Environ. Microbiol. 2004, 70, 1999-2012. [CrossRef] [PubMed]

41. Hwang, M.S.H.; Morgan, R.L.; Sarkar, S.F.; Wang, P.W.; Guttman, D.S. Phylogenetic characterization of virulence and resistance phenotypes of Pseudomonas syringae. Appl. Environ. Microbiol. 2005, 71, 5182-5191. [CrossRef]

42. Okonechnikov, K.; Golosova, O.; Fursov, M. Genome analysis Unipro UGENE: A unified bioinformatics toolkit. Bioinform. Appl. 2012, 28, 1166-1167. [CrossRef]

43. Larkin, M.A.; Blackshields, G.; Brown, N.P.; Chenna, R.; Mcgettigan, P.A.; Mcwilliam, H.; Valentin, F.; Wallace, I.M.; Wilm, A.; Lopez, R.; et al. Clustal W and Clustal X version 2.0. Bioinformatics 2007, 23, 2947-2948. [CrossRef]

44. Kumar, S.; Stecher, G.; Li, M.; Knyaz, C.; Tamura, K. MEGA X: Molecular Evolutionary Genetics Analysis across computing platforms. Mol. Biol. Evol. 2018, 35, 1547. [CrossRef] [PubMed]

45. Hillis, D.M.; Bull, J.J. An empirical test of bootstrapping as a method for assessing confidence in phylogenetic analysis. Syst. Biol. 1993, 42, 182-192. [CrossRef]

46. National Center for Biotechnology Information. Available online: https://www.ncbi.nlm.nih.gov / (accessed on 15 January 2018).

47. Ferrante, P.; Scortichini, M. Identification of Pseudomonas syringae pv. actinidiae as causal agent of bacterial canker of yellow kiwifruit (Actinidia chinensis Planchon) in central Italy. J. Phytopathol. 2009, 157, 768-770. [CrossRef]

48. Ferrante, P.; Scortichini, M. Molecular and phenotypic features of Pseudomonas syringae pv. actinidiae isolated during recent epidemics of bacterial canker on yellow kiwifruit (Actinidia chinensis) in central Italy. Plant Pathol. 2010, 59, 954-962. [CrossRef]

49. Sorensen, K.N.; Kim, K.H.; Takemoto, J.Y. PCR detection of cyclic lipodepsinonapeptide-producing Pseudomonas syringae pv. syringae and similarity of strains. Appl. Environ. Microbiol. 1998, 64, 226-230. [CrossRef] [PubMed]

50. Bereswill, S.; Bugert, P.; Volksch, B.; Ullrich, M.; Bender, C.L.; Geider, K. Identification and relatedness of coronatine-producing Pseudomonas syringae pathovars by PCR analysis and sequence determination of the amplification products. Appl. Environ. Microbiol. 1994, 60, 2924-2930. [CrossRef] [PubMed]

51. Templeton, M.D.; Reinhardt, L.A.; Collyer, C.A.; Mitchell, R.E.; Cleland, W.W. Kinetic analysis of the L-ornithine transcarbamoylase from Pseudomonas savastanoi pv. phaseolicola that is resistant to the transition state analogue $(\mathrm{R})-\mathrm{N} \delta-\left(\mathrm{N}^{\prime}-\right.$ sulfodiaminophosphinyl)-L-ornithine. Biochemistry 2005, 44, 4408-4415. [CrossRef]

52. GenBank Database. Available online: https://www.ncbi.nlm.nih.gov/genbank/ (accessed on 15 January 2019).

53. Tamura, K.; Nei, M. Estimation of the number of nucleotide substitutions in the control region of mitochondrial DNA in humans and chimpanzees. Mol. Biol. Evol. 1993, 10, 512-526. [CrossRef] [PubMed]

54. Parte, A.C. List of Prokaryotic names with standing in nomenclature (bacterio.net), 20 years on. Int. J. Syst. Evol. Microbiol. 2018, 68, 1825-1829. [CrossRef]

55. Lalucat, J.; Mulet, M.; Gomila, M.; García-Valdés, E. Genomics in bacterial taxonomy: Impact on the genus Pseudomonas. Genes 2020, 11, 139. [CrossRef]

56. Arnold, D.L.; Preston, G.M. Pseudomonas syringae: Enterprising epiphyte and stealthy parasite. Microbiology 2019, 165, $251-253$. [CrossRef] [PubMed]

57. Morris, C.E.; Monteil, C.L.; Berge, O. The life history of Pseudomonas syringae: Linking agriculture to earth system processes. Annu. Rev. Phytopathol. 2013, 51, 85-104. [CrossRef] [PubMed] 
58. Morris, C.E.; Sands, D.C.; Vanneste, J.L.; Montarry, J.; Oakley, B.; Guilbaud, C.; Glaux, C. Inferring the evolutionary history of the plant pathogen Pseudomonas syringae from its biogeography in headwaters of rivers in North America, Europe, and New Zealand. MBio 2010, 1, e00107-10. [CrossRef] [PubMed]

59. Young, J.M. Minireview taxonomy of Pseudomonas syringae. J. Plant Pathol. 2010, 92, S1.5-S1.14.

60. Baltrus, D.A.; McCann, H.C.; Guttman, D.S. Evolution, genomics and epidemiology of Pseudomonas syringae: Challenges in Bacterial Molecular Plant Pathology. Mol. Plant Pathol. 2017, 18, 152-168. [CrossRef] [PubMed]

61. Moore, W.E.C.; Stackebrandt, E.; Kandler, O.; Colwell, R.R.; Krichevsky, M.I.; Truper, H.G.; Murray, R.G.E.; Wayne, L.G.; Grimont, P.A.D.; Brenner, D.J.; et al. Report of the Ad Hoc committee on reconciliation of approaches to bacterial systematics. Int. J. Syst. Evol. Microbiol. 1987, 37, 463-464. [CrossRef]

62. Quigley, N.B. Syringomycin production among strains of Pseudomonas syringae pv. syringae: Conservation of the syrB and syrD genes and activation of phytotoxin production by plant signal molecules. Mol. Plant Microbe Interact. 1994, 7, 78. [CrossRef] [PubMed] 